\title{
FREQUENCY AND ASSOCIATIONS OF MARCUS GUNN PHENOMENON IN CONGENITAL PTOSIS
}

\author{
Maqsood Ahmad, Hafiza Sadia Imtiaz*, Usama Iqbal*, Muhammad Sharjeel**, Syed Imad Zahir, Ibrar Hussain \\ Khyber Teaching Hospital Peshawar Pakistan, *Gujranwala Medical Medical College, Gujranwala Pakistan, **Gomal Medical College DI Khan Pakistan,
}

\begin{abstract}
Objective: To determine the frequency and various associations of Marcus Gunn Phenomenon in patients of congenital ptosis. Study Design: Cross-sectional observational study.

Place and Duration of Study: Department of Ophthalmology, Khyber Teaching Hospital, Peshawar, from Jun to Sep 2020.

Methodology: A total of 100 patients with congenital ptosis were included. Patients with any cause of secondary or acquired ptosis were excluded. Congenital ptosis was classified as simple and complex. Assessment for ptosis severity, presence of jaw winking ptosis, jaw winking severity, refractive error, amblyopia, strabismus, systemic association and family history for congenital ptosis was performed.

Results: Simple congenital ptosis was the most common type overall (84\%). A total of $60 \%$ patients were males and $40 \%$ were females. More than $90 \%$ of the patients had severe ptosis. Ninety eight percent cases had onset since birth. No patient had systemic association or positive family history. Nine percent frequency of Marcus Gunn Phenomenon was noted with congenital ptosis. All the patients with Marcus Gunn Phenomenon had unilateral presentation. Left eye was affected predominantly $(88.89 \%)$. A total of $22.22 \%$ of the patients with Marcus Gunn Phenomenon had anisometropic amblyopia. No other ocular or systemic association of Marcus Gunn Phenomenon was observed.

Conclusion: Simple congenital ptosis is the most common type of congenital ptosis. The authors report $9 \%$ frequency of Marcus Gunn Phenomenon with congenital ptosis and left side effected predominantly. Anisometropic amblyopia was the major ocular association of Marcus Gunn Phenomenon observed.
\end{abstract}

Keywords: Association, Blinking, Blepharoptosis, Congenital, Jaw, Marcus gunn phenomenon, Reflex, Synkinesis.

This is an Open Access article distributed under the terms of the Creative Commons Attribution License (https://creativecommons.org/licenses/by-nc/4.0/), which permits unrestricted use, distribution, and reproduction in any medium, provided the original work is properly cited.

\section{INTRODUCTION}

Blepharoptosis or ptosis is the drooping of eyelid margin below its anatomical location with the eyeball in its primary position. Normally in adults, the upper eyelid is highest nasally and covers the cornea almost 1.5-2 $\mathrm{mm}$ below superior limbus ${ }^{1,2}$. According to time of onset, ptosis can be either congenital or acquired and according to etiology, acquired ptosis can be traumatic, neurogenic, myogenic, mechanical, and aponeurotic $^{3}$.

Congenital ptosis is drooping of eyelid below its anatomical position either at birth or within first year of life ${ }^{4}$. Congenital ptosis occurs due to dysgenesis of levator palpebrae superioris (LPS) muscle where normal muscle fibers are replaced by adipose and fibrous tissue resulting in decreased ability of LPS to contract and relax ${ }^{5}$. It can also occur due to interrupted innervation to LPS muscle thus representing a form of congenital cranial dysinnervation disorder ${ }^{6}$. Incidence of congenital ptosis was reported as 7.9 per 1 lac patients below 19 years of age ${ }^{7}$.

\section{Marcus Gunn Phenomenon (MGP) or Jaw}

Correspondence: Dr Usama Iqbal, Department of Ophthalmology, Gujranwala Medical College, Gujranwala Pakistan

Received: 24 Oct 2020; revised received: 26 Nov 2020; accepted: 01 Dec 2020 winking ptosisis a synkinesis where ptotic upper eyelid moves with the movement of jaw. This reflex consists of temporary upper eyelid elevation or retraction to the same or higher level as that of normal fellow eyelid, when there is stimulation of pterygoid muscles of same side. These patients have quite variable degrees of ptosis in resting primary position. It is usually unilateral but can also present as bilateral in rare cases $^{8}$. Pathophysiology of MGP suggests an abnormal connection between motor division of trigeminal nerve that supply external or internal pterygoid muscle and the superior branch of oculomotor nerve which supply the ipsilateral LPS muscle of upper lid 9 . Clinically, jaw winking ptosis can be associated with amblyopia, refractive errors, double elevator palsy, and superior rectus palsy. Jaw winking can be either mild $(<2 \mathrm{~mm})$, moderate $(2-5 \mathrm{~mm})$, or severe $(>5 \mathrm{~mm})^{9}$. There are various approaches for its management but overall surgical outcome is less favorable in congenital ptosis patients who have MGP rather than for those who don't have jaw-winking ${ }^{10}$.

In literature, data is lacking about the prevalence of MGP in patients with congenital ptosis. In addition whether it is more prevalent in patients who have congenital ptosis at birth or who develop later on within first year of life. Thus, the rationale of this study was 
made to determine the frequency of MGP in congenital ptosis patients and to determine its association with amblyopia, refractive error, and strabismus.

\section{METHODOLOGY}

After getting permission from ethics review committee (908/ADR/KMC), Khyber Medical College,

\section{RESULTS}

Mean age of included patients was $11.93 \pm 7.737$ years. All the patients had congenital ptosis. Gender distribution, age of onset (as noted by parents i.e. since birth or during first year of life) and laterality are shown in table-I.

Table-IV: Associations of marcus gunn jaw wink.

\begin{tabular}{l|c|c|c|c|c|c|c|c}
\hline \multirow{2}{*}{$\begin{array}{l}\text { Jaw Winking } \\
\text { Ptosis }\end{array}$} & \multicolumn{2}{|c|}{ Gender } & \multicolumn{2}{c|}{ Laterality } & \multirow{2}{*}{ Amblyopia } & \multirow{2}{*}{$\begin{array}{c}\text { Strabismus } \\
\text { Refractive } \\
\text { Error }\end{array}$} \\
\cline { 2 - 9 }$n$ & Male & Female & R & L & B & & - \\
\hline$p$-value & $5(55.55 \%)$ & $4(44.44 \%)$ & $1(11.11 \%)$ & $8(88.88 \%)$ & - & $2(22.22 \%)$ & $0.22 \%)$ \\
\hline
\end{tabular}

Peshawar, a cross-sectional observational study was conducted at department of ophthalmology, Khyber Teaching Hospital, Peshawar, Pakistan. Sample size of 96 was obtained with 95\% confidence level, anticipated population proportion of $50 \%$, and with absolute precision of $10 \%$ using WHO prevalence formula 7 . To make round figure 100 patients were included in this study. Consecutive sampling was used as a sampling technique. All the consenting patients, of both genders diagnosed as idiopathic congenital ptosis were included in the study. Patients with any cause of secondary or acquired ptosis like traumatic, third nerve palsy, Myasthenia gravis, Horner syndrome, chronic progressive external ophthalmoplegia, Duane syndrome and blephrophimosis syndrome were excluded from this study. Informed consent was taken from every patient/ guardian.

Patients were explained about the purpose and the benefits of the study and a specially designed proforma was used as data collection tool. Congenital ptosis was classified as simple and complex on the basis of ocular and systemic association. Assessment for refractive error or associated amblyopia was performed for all the patients included. The prevalence MGP was determined along with its association with amblyopia, refractive error, and strabismus.

All the included patients underwent the routine ophthalmic examination. Complete ptosis and squint evaluation was carried out. Slit-lamp bi-microscopy and fundoscopy was performed as well to exclude other causes of reduced visual acuity. Data was transferred from the pro-forma to SPSS-20. Mean of age of all the presenting patients was computed. Frequencies were calculated to describe all the nominal variables. Chi-square test was applied to check association of Marcus Gunn Phenomenon with gender, laterality, amblyopia, strabismus and refractive error.
Eighty four patients had simple congenital ptosis i.e. with no ocular or systemic manifestation. Sixteen patients had complex congenital ptosis. On severity grading, 78 patients had ptosis $>4 \mathrm{~mm}, 14$ patients had ptosis between $3-4 \mathrm{~mm}, 7$ patients had ptosis between 1-2mm. Manifestations of complex congenital ptosis and patients who had associated refractive error, amblyopia and positive family history for congenital ptosis are given in table-II.

Table-I: Demographic detail of patients with congenital ptosis.

\begin{tabular}{|c|c|}
\hline & Mean \\
\hline Age at presentation (years) & $11.93 \pm 7.737$ \\
\hline Gender Distribution & Frequency (\%) \\
\hline Male & $60(60 \%)$ \\
\hline Female & $40(40 \%)$ \\
\hline \multicolumn{2}{|l|}{ Age of Onset } \\
\hline Since Birth & $98(98 \%)$ \\
\hline Since Childhood (1st Year) & $2(2 \%)$ \\
\hline \multicolumn{2}{|l|}{ Laterality } \\
\hline Right Side & $41(41 \%)$ \\
\hline Left Side & $36(36 \%)$ \\
\hline Bilateral & $23(23 \%)$ \\
\hline
\end{tabular}

Jaw winking ptosis was graded as mild $(<2 \mathrm{~mm})$, moderate $(2-5 \mathrm{~mm})$, or severe $(>5 \mathrm{~mm})$ (table-III). Cross tabulation of Marcus Gunn phenomenon with gender, laterality, amblyopia, strabismus and refractive error is shown in table-IV.

\section{DISCUSSION}

Incidence of congenital ptosis is reported as 7.9 per 100,000 patients in a population based report of 40 years $^{7}$. In a study done at Al-Shifa Eye Hospital, Rawalpindi, Pakistan frequency of congenital ptosis was reported $(8.8 \%)$ among all the cases of congenital ophthalmic malformations. It was concluded that it is the $3^{\text {rd }}$ most common congenital ophthalmic malformation $^{11}$. Niazi observed (55.55\%) occurrence in male and $(44.44 \%)$ in females ${ }^{11}$. Similar trends were observed in 
Table-II: Classification, severity and associations.

\begin{tabular}{l|c}
\hline Associations of congenital ptosis & n (\%) \\
\hline Congenital Ptosis & $84(84 \%)$ \\
\hline Simple & $16(16 \%)$ \\
Complex & $7(7 \%)$ \\
\hline Ptosis Severity (n=100) & $14(14 \%)$ \\
\hline Mild (1-2 mm) & $78(78 \%)$ \\
Moderate (3-4mm) & History \\
Severe (>4mm) & $26(26 \%)$ \\
\hline Refractive Error, Amblyopia or Family & $28(28 \%)$ \\
Association (n=100) & $2(2 \%)$ \\
\hline Refractive Error & \\
Amblyopia & $9(56.25 \%)$ \\
Positive Family History for congenital ptosis & $7(43.75 \%)$ \\
\hline Complex Congenital Ptosis (n=16) & - \\
\hline Marcus Gunn phenomenon & Associated Squint \\
Systemic Association & $\mathbf{n}(\%)$ \\
\hline Table-III: Jaw winking ptosis severity (n=9). \\
\hline Severity of Jaw winking ptosis \\
\hline Mild (<2mm) (33.33\%) \\
Moderate (2-5 mm) \\
Severe (>5 mm)
\end{tabular}

our study with $60 \%$ and $40 \%$ male and female distribution. Left sided congenital ptosis is reported more frequently in literature $7,9,12$. In our study, right sided congenital ptosis was more common. In our study, only the patients with congenital ptosis were included. Acquired ptosis was not included. This can be the reason for this difference in laterality. Left sided ptosis is reported to be associated with Duane retraction syndrome most of the time ${ }^{7}$, which was excluded in our study. Twnty three percent patients in our study had bilateral congenital ptosis. Bilateral congenital ptosis is reported about $3-7 \%$ in different reports $4,7,12$. In our study bilateral cases are reported in far major number. This can be because of single center study setting or due to referral of patients with severe congenital malformation to tertiary care teaching hospital.

A total $98 \%$ patients in our study had presumed congenital onset of ptosis. Majority of the included patients $(84 \%)$ had simple congenital ptosis. In a $24-$ year report of blepharoptosis in Korea, simple congenital ptosis was reported to be the most common type of congenital ptosis overall with a frequency of $73.7 \% 12$. Gregory et al, also reported simple congenital ptosis as the most common type with $76 \%$ of the patients with childhood ptosis labelled as simple congenital ptosis ${ }^{7}$. Similar trends were observed in our study. More than $90 \%$ patients in our study had moderate to severe ptosis. Severe ptosis is more common in case of congenital ptosis while in acquired ptosis mild-moderate ptosis severity is encountered more frequently ${ }^{12}$.

In a meta-analysis by Yijie et al, the prevalence of amblyopia in congenital ptosis ranged from 18.5$27.8 \% 13$. In our study $28 \%$ patients had associated amblyopia with congenital ptosis. Twenty six percent patients in our study also had associated refractive error. Associated strabismus was found in $8 \%$ of the patients. Higher prevalence $(19.6 \%)$ of strabismus is reported in recent meta-analysis ${ }^{13}$. No patient had any systemic association or family history for ptosis in our study.

The incidence of Marcus Gunn phenomenon (MGP) ranges between 2-13\% in patients with congenital ptosis9. A 10 year review on childhood ptosis in UK has shown $5 \%$ prevalence of jaw winking ptosis ${ }^{14}$. In a 3 year review of congenital ptosis at Mayo Hospital, Lahore $11 \%$ patients had jaw winking ptosis ${ }^{15}$. In our study 9\% prevalence of Marcus Gunn phenomenon was noted in patients of congenital ptosis.

No gender dominance was noted. Five patients $(n=9)$ were males, while $4(n=9)$ were females. Pearce $e t$ $a l$ in their second largest case series on MGP noted a trend toward female gender with MGP and congenital ptosis but this was reported to be statistically insignificant ${ }^{16}$. A total of $88.89 \%$ patients in our study had left sided jaw winking ptosis. Left sided predominance in jaw winking is reported in literature9,16,17. Qirat et al in a case series on jaw winking ptosis treatment, performed in Karachi, Pakistan, reported $72.7 \%$ occurrence on left side ${ }^{18}$. All the patients in our study had unilateral MGP. Bilateral MGP is also reported in literature but is rare overall16,19.

Severity of jaw winking ptosis was graded on the basis of excursion of upper eyelid on mouth opening 9 . Six patients $(n=9)$ had severe jaw winking while 3 patients $(n=9)$ has mild jaw winking. Ocular associations with MGP observed in our study were amblyopia and refractive errors. In our study, 2 patients $(n=9)$ had associated amblyopia with MGP. Both patients had anisometropic amblyopia. In literature, the most common ocular association of MGP reported is strabismus (50$60 \%$ ) followed by amblyopia $(30-60 \%)^{20}$. Other ocular associations of MGP include double elevator palsy $(25 \%)^{15,20}$ and superior rectus palsy $(25 \%)^{20}$. These ocular associations were not observed in our study because of small sample size and study duration. Recent case reports also show association of MGP with morning glory optic disc anomaly ${ }^{21}$. It is also reported that MGP can even present without blepharoptosis ${ }^{22}$. 
Limitations of our study include single center, small duration of study and small sample size.

\section{CONCLUSION}

Simple congenital ptosis is the most common type of congenital ptosis. The authors report $9 \%$ prevalence of MGP with congenital ptosis and left side effected predominantly. Anisometropic amblyopia was the major ocular association of MGP observed.

\section{CONFLICT OF INTEREST}

This study has no conflict of interest to be declared by any author.

\section{REFERENCES}

1. Gomez J, Laquis SJ. Blepharoptosis: clinical presentation, diagnosis, and treatment. Insight 2015; 40(2): 5-9.

2. Sruthi R, Pauly M. Ptosis: Evaluation and management. Kerala J Ophthalmol 2019; 31(1): 11-16.

3. Lim JM, Hou JH, Singa RM, Aakalu VK, Setabutr P. Relative incidence of blepharoptosis subtypes in an oculoplastics practice at a tertiary care center. Orbit 2013; 32(4): 231-34.

4. Marenco M, Macchi I, Macchi I, Galassi E, Massaro - Giordano G, Lambiase A. Clinical presentation and management of congenital ptosis. Clin Ophthalmol 2017; 11: 453-63.

5. Surve A, Sharma M, Pushker N, Bajaj M, Meel R, Kashyap S. A study of changes in levator muscle in congenital ptosis. Int Ophthalmol 2019; 39(6): 1231-38.

6. Mendes S, Beselga D, Campos S, Neves A, Campos J, Carvalho S, et al. Possible rare congenital dysinnervation disorder: congenital ptosis associated with adduction. Strabismus 2015; 23(1): 33-35.

7. Griepentrog G, Diehl N, Mohney B. Incidence and demographics of childhood ptosis. Ophthalmology 2011; 118(6): 1180-83.

8. Sobel R, Allen R. Incidence of bilateral Marcus Gunn jaw-wink. Ophthalmic Plast Reconstr Surg 2014; 30(3): e54-55.

9. Senthilkumar VA, Tripathy K. Marcus gunn jaw winking syndrome. [Updated 2020 Aug 10]. In: StatPearls. Treasure Island
(FL): Stat Pearls Publishing; 2020. [Internet] Available from: https://www.ncbi.nlm.nih.gov/books/NBK559058/ (Assessed at: 10 Aug, 2020).

10. Ho YF, Wu SY, Tsai YJ. Factors associated with surgical outcomes in congenital ptosis: A 10-year study of 319 cases. Am J Ophthalmol 2017; 175: 173-82.

11. Niazi SHK. Congenita ptosis; Frequency of congenital ptosis. Prof Med J 2020; 27(8): 1602-05.

12. Lee YG, Son BJ, Lee KH, Lee SY, Kim CY. Clinical and demographic characteristics of blepharoptosis in Korea: A 24-year experience including 2,328 patients. Korean J Ophthalmol 2018; 32(4): 249-56.

13. Wang Y, Xu Y, Liu X, Lou L, Ye J. Amblyopia, strabismus and refractive errors in congenital ptosis: a systematic review and meta-analysis. Sci Rep 2018; 8(1): 1-9.

14. Berry-Brincat A, Willshaw H. Paediatricblepharoptosis: a 10-year review. Eye 2009; 23(7): 1554-59.

15. Moin M. Association of double elevator palsy with jaw winking ptosis. Pak Postgrad Med J 2017; 28(1): 26-30.

16. Pearce FC, McNab AA, Hardy TG. Marcus gunn jaw-winking syndrome: A comprehensive review and report of four novel cases. Ophthalmic Plast Reconstr Surg 2017; 33(5): 325-28.

17. Falcão I, Almeida F. Marcus Gunn Phenomenon. J Pediatr 2017; 188: 302.

18. Qurban Q, Kamil Z, Mahmood K. Treatment of Marcus Gunn jaw winking ptosis. J Surg Pak 2020; 25(2): 60-64.

19. Shah AD, Kumar AB, Kothari K. Bilateral marcus gunn jaw winking synkinesis with monocular elevation deficiency: a case report and literature review. Int Ophthalmol 2012; 32(2): 199-201.

20. Gomez, VMP, Ganatra, SR. Marcus-Gunn jaw winking ptosis [Internet]. Available from: https://eyewiki.aao.org/MarcusGunn_jaw_winking_ptosis (Assessed at: 10 Aug, 2020)

21. Alshamrani AA, Alghulaydhawi FA, Al Shamrani M. Marcus gunn jaw-winking syndrome associated with morning glory disc anomaly. Middle East Afr J Ophthalmol 2019; 26(1): 37.

22. Alam MS, Nishanth $S$, Ramasubramanian $S$, Swaminathan $M$, Mukherjee B. The rare phenomenon of Marcus-Gunn jaw winking without ptosis: report of 14 cases and review of the literature. Indian J Ophthalmol 2020; 68(6): 1132. 